Original article

\title{
Communication with patients and colleagues in rehabilitation process: needs, expectations and responsibility of the orthopedic surgeons
}

\author{
Alexander S. Fedonnikov
}

Saratov State Medical University, Saratov, Russia

Received 9 April 2019, Revised 3 June 2019, Accepted 17 July 2019

(C) 2019, Fedonnikov A.S.

(C) 2019, Russian Open Medical Journal

\begin{abstract}
The aim of the study is to elicit orthopedic surgeons' needs, expectations and responsibility concerning communication with their patients in rehabilitation period.

Material and Methods - A sociological research was conducted in the form of in-person survey and included 41orthopedic surgeons of one of six specialized scientific and medical orthopedic centers in the European part of Russia.

Results - The performed study has shown that $39 \%$ of respondents admit that the hospital having provided the surgery should get the information about patients' further rehabilitation throughout the first 6 months after it while $41.5 \%$ offer more prolonged period - one year after the surgery. Positive attitude to communication with patients and colleagues in postoperative period to exchange the current results of clinical and introscopic examinations is demonstrated by $87.8 \%$ of interviewed specialists. Among the distant ways of communication, the most preferable are messengers and phone conversations (average ranking place -3.8 out of 7 ), the least preferable are social networks (average ranking place -4.9 out of 7 ).

Conclusion - On the basis of the conducted study the orthopedic surgeons' understanding of the necessity to be informed about the rehabilitation process after the surgery and to be ready to use different ways of distant communication has been discovered. Nevertheless, the probable obstacle in Russia for the introduction of feedback practice from patients during rehabilitation period are exceeding workload of orthopedic surgeons and their disinclination to involve regional nurses and social carers in rehabilitation process support.
\end{abstract}

Keywords: online communication, feedback from patients, digital health, orthopedic surgeons, rehabilitation.

Cite as Fedonnikov AS. Communication with patients and colleagues in rehabilitation process: needs, expectations and responsibility of the orthopedic surgeons. Russian Open Medical Journal 2019; 8: e0306.

Correspondence to Alexander S. Fedonnikov. Address: Scientific and Research Institute of Traumatology, Orthopedics and Neurosurgery, Saratov State Medical University n.a. V.I. Razumovsky, 148, Chernyshevskogo str., Saratov, 410002, Russia. Phone: +7-905-3682997. E-mail: fedonnikov@mail.ru.

\section{Introduction}

The United Nations, the World Health Organization and the World Bank experts recognize the significant medical and social consequences of muscular-skeletal diseases including patients' disability, personal and economic independence which influence world disease burden considerably [1]. Hip and knee osteoarthritis dominates in their nosologic structure [2]. Hip and knee arthroplasties have been used widely for more than 40 years: in some West European countries the annual number of surgeries makes up 300-400 thousand, in the USA it approaches 1 million [3]. In Russia the same type of surgeries comprises more than 100 thousand annually having increased 2.5 times during the last 10 years [4] which leads to the appearance of great number of implanted patients requiring continuous rehabilitation support throughout all their lives. However according to the results of our previous studies it is not provided properly - about $30 \%$ of the patients are not able to consult a doctor at the place of their residence, more than $90 \%$ point out the lack of feedback from regional health authorities having referred them for surgeries [5]. It should be mentioned that there are successful examples of remote management of musculoskeletal diseases [6]. The aim of the study is to elicit orthopedic surgeons' needs, expectations and responsibility concerning communication with their patients in rehabilitation period.

\section{Material and Methods}

Design

A sociological research was conducted in the form of in-person survey at the beginning of the workday just after doctors' briefing.

\section{Subjects}

The respondents of the survey are 41 orthopedic surgeons of the Research Institute of traumatology, orthopedics and neurosurgery of Saratov State Medical University (Saratov, Russia) which is one of six specialized scientific and medical orthopedic centers in the European part of Russia delivering about $5 \%$ of hip and knee arthroplasties.

The research covered the group of junior doctors (19.5\%), orthopedic surgeons (46.3\%) and heads of department (7.3\%). $29.3 \%$ of them have PhD academic degree (Table 1). The majority of respondents $(61 \%)$ are the experienced surgeons having worked more than 10 years, $68.3 \%$ have an experience in arthroplasty more than 5 years (Table 2 ). 
Table 1. Distribution of respondents on the basis of their position and academic degree, no (\%)

\begin{tabular}{lccc|ccc}
\hline \multicolumn{3}{c|}{ Position } & \multicolumn{2}{c}{ Scientific degree } \\
\hline Junior & $\begin{array}{c}\text { Orthopedic } \\
\text { Doctor }\end{array}$ & $\begin{array}{c}\text { Head of } \\
\text { surgeon }\end{array}$ & $\begin{array}{c}\text { orthopedic } \\
\text { department }\end{array}$ & $\begin{array}{c}\text { Not } \\
\text { specified }\end{array}$ & PhD & None \\
$8(19.5)$ & $19(46.3)$ & $3(7.3)$ & $11(26.8)$ & $12(29.3)$ & $29(70.7)$ \\
\hline
\end{tabular}

PhD, Doctorate of Philosophy or its equivalent.

Table 2. Distribution of experts on the basis of general medical training and work experience in spinal surgery, no (\%)

\begin{tabular}{lcccc}
\hline \multicolumn{1}{c}{ Period } & $\begin{array}{c}\text { up to } 5 \\
\text { years }\end{array}$ & $\begin{array}{c}5-10 \\
\text { years }\end{array}$ & $\begin{array}{c}11-20 \\
\text { years }\end{array}$ & $\begin{array}{c}\text { More than } \\
20 \text { years }\end{array}$ \\
\hline $\begin{array}{l}\text { General experience } \\
\begin{array}{l}\text { Experience in } \\
\text { arthroplasty }\end{array}\end{array}$ & $13(31.7)$ & $3(7.3)$ & $15(36.6)$ & $10(24.4)$ \\
\hline
\end{tabular}

Table 3. Distribution the opinion concerning the practice of communication with patients and colleagues in postsurgical period, no (\%)

\begin{tabular}{lccc}
\hline $\begin{array}{l}\text { Attitude to communication } \\
\text { in postoperative period }\end{array}$ & Patients & $\begin{array}{c}\text { Players of communication } \\
\text { Colleagues from } \\
\text { other hospitals }\end{array}$ & P-level \\
\hline $\begin{array}{l}\text { I consider it normal practice } \\
\text { in terms of my working } \\
\text { duties }\end{array}$ & $26(63.4)$ & $19(46.3)$ & 0.123 \\
\hline $\begin{array}{l}\text { I'm ready to participate in } \\
\text { this kind of activity for } \\
\text { additional compensation }\end{array}$ & $10(24.4)$ & $17(41.5)$ & 0.103 \\
\hdashline $\begin{array}{l}\text { No, I don't consider it } \\
\text { possible for myself }\end{array}$ & $3(7.3)$ & $1(2.4)$ & 0.305 \\
- & $2(4.9)$ & $4(9.8)$ & 0.398 \\
\hline Neitheragreenordisagree & & &
\end{tabular}

\section{Questionnaire}

The questionnaire, which was specially designed by us and intended for the research of orthopedic surgeons' needs for communication and feedback with patients in postoperative period, consists of two sections concerning different subjects. The first part includes questions dealing with identification and evaluation of communication opportunities and their methods and issues as well. The second part contains the questions concerning surgeons' professional level and work experience. The questionnaire's fulltext is presented in Appendix 1.

\section{Statistical analysis}

Data are presented as frequencies and percentages - no. (\%). Frequencies are compared with Chi-squared $\left(\chi^{2}\right)$ test.

\section{Results}

The performed study has shown that $39 \%$ of respondents admit that the hospital having provided the surgery should get the information about patients' further rehabilitation throughout the first 6 months after it while $41.5 \%$ offer more prolonged period one year after the surgery. Positive attitude to communication with patients and colleagues in postoperative period to exchange the current results of clinical and introscopic examinations is demonstrated by $87.8 \%$ of interviewed specialists. $24.4 \%$ are ready to get feedback from patients and $41.5 \%$ dispose themselves for communicating with their colleagues from other hospitals on the questions of complicated cases including further patients' routing and assigning of supplementary consultations in case they can expect additional compensation (Table 3).

The analysis of the acceptable ways of communication with patients in postsurgical period (Table 4) shows that most of orthopedic surgeons prefer direct communication during medical consultation (63.4\%; average ranking place -2.2 out of 7). Among the distant ways of communication the most preferable are messengers and phone conversations (average ranking place -3.8 out of 7), the least preferable are social networks (average ranking place -4.9 out of 7 )

The analysis of the acceptable ways of communication with colleagues in postsurgical period (Table 5) shows that most of orthopedic surgeons prefer direct communication during personal contact (63.4\%; average ranking place -2.3 out of 7). Among the distant ways of communication the most preferable is the phone conversations (average ranking place -3.1 out of 7 ), the least preferable are social networks (average ranking place -5.0 out of 7).

The opinions of orthopedic surgeons about the responsible players for patents' support during postsurgical period and the barriers preventing doctors from providing it are presented in Table 6.

\section{Discussion}

The analysis of provided study results made it possible to outline the major aspects of understanding and needs of orthopedic surgeons in arranging communication with patients during the period of postsurgical rehabilitation. First of all, what has been discovered is the existence of the gap between the formal agreement of doctors to be informed about the rehabilitation process after the surgery and their actual desire to be involved in getting feedback from patients. More than $92 \%$ of the surveyed are generally interested in getting the information about further rehabilitation after the surgery. However, no more than a quarter of surgeons are ready to get feedback from patients personally whereas about $40 \%$ of them agree to communicate with the colleagues from other hospitals on the questions of complicated cases including further patients' routing and assigning of supplementary consultations. Most of orthopedic surgeons $(65.9 \%)$ mention that patients' support after the surgery is the responsibility of primary care physicians at the place of a patient residence. This idea theoretically matches the logic of continuity of health care providing but the lack of primary care physicians goes up to $40 \%$ in different regions of Russia (especially in the countryside) $[7,8]$ which makes it hard to bring it to life. It should be considered that the problem of rehabilitation shortage is mentioned in other studies [9] emphasizing the discrimination of certain social groups (for example senior citizens).

The fact that $17.1 \%$ of respondents assert that experienced orthopedic surgeons of the hospital providing surgery should be involved in patents' support during postsurgical period confirms the understanding the situation of rehabilitation shortage in Russian regions and readiness to participate in this process distantly. As well as this they have no inclination to delegate authorities concerning support and control of rehabilitation process to nurses and social carers despite the lack doctors at the place of patients' residence. Situation in world practice is absolutely different - the support of rehabilitation process is considered to be the responsibility of nursing services $[10,11]$. 
Table 4. Acceptance of the ways of communication with patients while getting feedback, no (\%)

\begin{tabular}{|c|c|c|c|c|c|c|c|c|}
\hline \multirow[b]{2}{*}{ Way of communication } & \multicolumn{7}{|c|}{ Distribution of respondents } & \multirow{2}{*}{$\begin{array}{l}\text { Average } \\
\text { ranking } \\
\text { place }\end{array}$} \\
\hline & $\begin{array}{l}\text { I ranking } \\
\text { place }\end{array}$ & $\begin{array}{l}\text { II ranking } \\
\text { place }\end{array}$ & $\begin{array}{l}\text { III ranking } \\
\text { place }\end{array}$ & $\begin{array}{l}\text { IV ranking } \\
\text { place }\end{array}$ & $\begin{array}{l}\text { V ranking } \\
\text { place }\end{array}$ & $\begin{array}{l}\text { VI ranking } \\
\text { place }\end{array}$ & $\begin{array}{l}\text { VII ranking } \\
\text { place }\end{array}$ & \\
\hline Direct communication during medical consultation & $26(63.4)$ & $3(7.3)$ & $2(4.9)$ & $3(7.3)$ & $4(9.8)$ & $2(4.9)$ & $1(2.4)$ & 2.2 \\
\hline Distant communication by phone & 0 & $11(26.8)$ & $10(24.4)$ & $7(17.1)$ & $6(14.6)$ & $2(4.9)$ & $5(12.2)$ & 3.8 \\
\hline Distant communication by e-mail & $3(7.3)$ & $5(12.2)$ & $6(14.6)$ & $5(12.2)$ & $9(22.0)$ & $7(17.1)$ & $6(14.6)$ & 4.4 \\
\hline Distant communication by video call (Skype) & 0 & $6(14.6)$ & $9(22.0)$ & $7(17.1)$ & $5(12.2)$ & $11(26.8)$ & $3(7.3)$ & 4.4 \\
\hline $\begin{array}{l}\text { Distant communication by means of messengers } \\
\text { (WhatsApp, Viber etc.) }\end{array}$ & $7(17.1)$ & $6(14.6)$ & $5(12.2)$ & 6 (14.6) & 7 (17.1) & 7 (17.1) & $3(7.3)$ & 3.8 \\
\hline $\begin{array}{l}\text { Distant communication by means of social networks } \\
\text { (Facebook, Instagram, VK etc.) }\end{array}$ & $2(4.9)$ & $5(12.2)$ & $1(2.4)$ & 8 (19.5) & 6 (14.6) & 9 (22.0) & $10(24.4)$ & 4.9 \\
\hline $\begin{array}{l}\text { Interactive online communication platform with } \\
\text { personal area authentication (having function of } \\
\text { data exchange including voice and video calls) }\end{array}$ & $3(7.3)$ & $5(12.2)$ & $8(19.5)$ & $5(12.2)$ & $4(9.8)$ & $3(7.3)$ & $13(31.7)$ & 4.5 \\
\hline
\end{tabular}

Table 5. Acceptance of the ways of communication with colleagues while getting feedback, no (\%)

\begin{tabular}{|c|c|c|c|c|c|c|c|c|}
\hline \multirow[b]{2}{*}{ Way of communication } & \multicolumn{7}{|c|}{ Distribution of respondents } & \multirow{2}{*}{$\begin{array}{l}\text { Average } \\
\text { ranking } \\
\text { place }\end{array}$} \\
\hline & $\begin{array}{l}\text { I ranking } \\
\text { place }\end{array}$ & $\begin{array}{l}\text { II ranking } \\
\text { place }\end{array}$ & $\begin{array}{l}\text { III ranking } \\
\text { place }\end{array}$ & $\begin{array}{l}\text { IV ranking } \\
\text { place }\end{array}$ & $\begin{array}{l}\text { V ranking } \\
\text { place }\end{array}$ & $\begin{array}{l}\text { VI ranking } \\
\text { place }\end{array}$ & $\begin{array}{l}\text { VII ranking } \\
\text { place }\end{array}$ & \\
\hline Direct communication during personal contact & $26(63.4)$ & $4(9.8)$ & $4(7.3)$ & - & $2(4.9)$ & $2(4.9)$ & $4(9.8)$ & 2.3 \\
\hline Distant communication by phone & $5(12.2)$ & $18(43.9)$ & $3(7.3)$ & $5(12.2)$ & $3(7.3)$ & $5(12.2)$ & $2(4.9)$ & 3.1 \\
\hline Distant communication by e-mail & $1(2.4)$ & $1(2.4)$ & $14(34.1)$ & $7(17.1)$ & $6(14.6)$ & $5(12.2)$ & $7(17.1)$ & 4.4 \\
\hline Distant communication by video call (Skype) & - & $3(7.3)$ & $12(29.3)$ & $6(14.6)$ & $9(22.0)$ & $7(17.1)$ & $4(9.8)$ & 4.4 \\
\hline $\begin{array}{l}\text { Distant communication by means of messengers } \\
\text { (WhatsApp, Viber etc.) }\end{array}$ & $4(9.8)$ & $5(12.2)$ & $7(17.1)$ & $9(22.0)$ & $8(19.5)$ & $8(19.5)$ & - & 3.9 \\
\hline $\begin{array}{l}\text { Distant communication by means of social } \\
\text { networks (Facebook, Instagram, VK etc.) }\end{array}$ & $1(2.4)$ & $5(12.2)$ & $1(2.4)$ & 6 (14.6) & $9(22.0)$ & $10(24.4)$ & $9(22.0)$ & 5.0 \\
\hline $\begin{array}{l}\text { Interactive online communication platform with } \\
\text { personal area authentication (having function of } \\
\text { data exchange including voice and video calls) }\end{array}$ & $4(9.8)$ & $6(14.6)$ & $1(2.4)$ & $8(19.5)$ & $4(9.8)$ & $4(9.8)$ & $14(34.1)$ & 4.7 \\
\hline
\end{tabular}

Table 6. Players responsible for patients' support after the surgery and barriers preventing surgeons from providing it, no (\%)

\begin{tabular}{|c|c|c|c|c|c|c|c|}
\hline \multicolumn{5}{|c|}{ Players responsible for patients' support after the surgery } & \multicolumn{3}{|c|}{$\begin{array}{l}\text { Barriers preventing surgeons from patients' } \\
\text { support after the surgery }\end{array}$} \\
\hline $\begin{array}{l}\text { Primary care physicians } \\
\text { at the place ofresidence }\end{array}$ & $\begin{array}{l}\text { Experienced orthopedic } \\
\text { surgeons of the hospital } \\
\text { providing surgery }\end{array}$ & $\begin{array}{l}\text { Specially trained } \\
\text { nurses at the place } \\
\text { of residence }\end{array}$ & $\begin{array}{l}\text { Social carers } \\
\text { at the place } \\
\text { of residence }\end{array}$ & Other & $\begin{array}{l}\text { Exceeding } \\
\text { workload }\end{array}$ & $\begin{array}{l}\text { Necessity } \\
\text { is not } \\
\text { clear }\end{array}$ & $\begin{array}{c}\text { Considering it } \\
\text { optional }\end{array}$ \\
\hline $27(65.9)$ & $7(17.1)$ & $4(9.8)$ & $2(4.9)$ & $1(2.4)$ & $27(65.9)$ & $6(14.6)$ & $4(9.8)$ \\
\hline
\end{tabular}

The expressed opinions of medical specialists show that at the age of medicine digital transformation orthopedic surgeons are not always ready to use modern technologies of communication with patients yet their priority is direct (visual) contact with them. It might be connected with fact that the system of Russian medical education reproduces traditional model of communication between the doctor and the patient.

The inclination of medical specialists to prefer messengers to the other ways of distant communication with patients in course of media content, clinical and introscopic data exchange is the result of their high demand in daily routine due to convenience and functionality. Along with this while contacting with colleagues they prefer phone conversation which is possibly connected with the need of professional communication as well as correct and confidential transfer of the information.

Thus, in spite of the fact that the orthopedic surgeons expressed their readiness to interact and be involved in rehabilitation process by means of online communication, the majority of them (65.9\%) indicated the exceeding workload as the main barrier for patents' support in postsurgical period.

\section{Conclusion}

On the basis of the conducted study the orthopedic surgeons' understanding of the necessity to be informed about the rehabilitation process after the surgery and to be ready to use different ways of distant communication has been discovered. Nevertheless the probable obstacle in Russia for the introduction of feedback practice from patients during rehabilitation period are exceeding workload of orthopedic surgeons and their disinclination to involve regional nurses and social carers in rehabilitation process support.

\section{Limitations}

The limitation for the study is including the respondents of only one specialized scientific and medical orthopedic center and not massive sampling which might affect representativeness of the results. 


\section{Funding}

The article is prepared with the financial support of Russian Foundation for Basic Research, project №19-013-00766 «Online communication as a factor of medical technologies efficiency for labor activity prolongation».

\section{Conflict of Interest}

Author has no conflict of interest.

\section{Ethical approval}

All procedures performed in studies involving human participants were in accordance with the ethical standards of the institutional research committee and with the 1964 Helsinki declaration and its later amendments or comparable ethical standards.

\section{References}

1. Global diffusion of eHealth: making universal health coverage achievable. Report of the third global survey on eHealth. Geneva: World Health Organization, 2016; 156 p. https://www.who.int/goe/publications/global_diffusion/en.

2. The Bone and Joint Decade. Global Alliance for Musculoskeletal Health. Key facts from The Global Burden of Disease 2012. http://bjdonline.org/?page id=1574.

3. Chechik O, Khashan M, Lador R, Salai M, Amar E. Surgical approach and prosthesis fixation in hip arthroplastyworld. Arch Orthop Trauma Surg 2013; 133(11): 1595-1600. https://doi.org/10.1007/s00402-0131828-0.

4. Traumatism, orthopedic incidence, state of traumatology and orthopedic care for the population of Russian in 2017. S.P. Mironov, ed. Moscow, Russia: FSBI CITO n.a. N.N Priorova, 2018; 145 p. Russian.

5. Fedonnikov AS, Andriyanova EA, Erugina MV, Norkin IA. Rehabilitation after hip and knee joints replacement: several results of medical and sociological monitoring. Saratov J Med Sci Res 2017; (13)4: 796-799. Russian. https://elibrary.ru/item.asp?id=35143215.

6. Vallati C, Virdis A, Gesi M, Carbonaro N, Tognetti A. ePhysio: a wearables-enabled platform for the remote management of musculoskeletal diseases. Sensors (Basel) 2018; 19(1), E2. https://doi.org/10.3390/s19010002.

7. Accounting Chamber checked optimization in the field of health care, culture, education and social services. Accounting Chamber of Russian Federation, 2015. http://www.ach.gov.ru/press center/news/21297.

8. Statistic information of the Ministry of Health of Russia, 2012. https://www.rosminzdrav.ru/documents/6686-statisticheskayainformatsiya.

9. Esquivel KM, Nevala E, Alamaki A, Condell J, Kelly D, Davies R, et al. Remote rehabilitation: a solution to overloaded \& scarce health care systems. Trends in Telemedicine \& E-health 2018; 1(1): 1-19. https://crimsonpublishers.com/tteh/pdf/TTEH.000503.pdf.

10. Brillhart B, Heard L, Kruse B. Rehabilitation nursing in home care. $\begin{array}{llll}\text { Rehabil Nurs 2001; 26(5): } 177-181, & 191 .\end{array}$ https://www.ncbi.nlm.nih.gov/pubmed/12035686.

11. Camicia M, Black T, Farrell J, Waites K, Wirt S, Lutz B. The essential role of the rehabilitation nurse in facilitating care transitions: a white paper by the association of rehabilitation nurses. Rehabil Nurs 2014; 39(1): 315. https://doi.org/10.1002/rnj.135.

\section{Authors:}

Alexander S. Fedonnikov - MD, PhD, Vice rector for research, Saratov State Medical University, Saratov, Russia; Head of Department of Innovative Technologies in Medical Care and Rehabilitation, Research Institute of Traumatology, Orthopedics and Neurosurgery, Saratov State Medical University, Saratov, Russia. http://orcid.org/0000-0003-03444419 


\section{Appendix 1. Fulltext of questionnaire}

Dear Colleague,

Research Institute of Traumatology, Orthopedics and Neurosurgery of Saratov State Medical University is conducting the survey to identify the areas of improving the communication between the doctors and patients in the period of postsurgical rehabilitation. We kindly ask you to take part in this study.

Your opinion is very important for us.

While working with the questionnaire please tick the answers you have chosen or write down your own one.

Please take notice that questions 1-5, 8, 9, 12 are supposed to have one answer, questions 6,7 are supposed to have several answers.

\section{SPECIAL SECTION}

1. Do you think that hospital having provided the surgery should get the information about patients' further rehabilitation?

1.1. Yes, throughout the first six months

1.2. Yes, throughout the first year

1.3. Yes, throughout the whole life of patient

1.4. No, I don't think it is necessary for the hospital where the surgical stage of treatment is provided

2. Are you ready to participate in communication with patients in postsurgical period (including exchanging the current results of their clinical and introscopic examinations):

2.1. Yes, I consider it normal practice in terms of my working duties

2.2. Yes, I'm ready to participate in this kind of activity for additional compensation (extra payment etc.)

2.3. No, I don't consider it possible for myself

2.4. Neither agree nor disagree

3. Are you ready to participate in communication with colleagues from other hospitals supporting the patient in postsurgical period (including exchanging the current results of clinical and introscopic examinations):

3.1. Yes, I consider it normal practice in terms of my working duties

3.2. Yes, I'm ready to participate in this kind of activity for additional compensation (extra payment etc.)

3.3. No, I don't consider it possible for myself

3.4. Neither agree nor disagree

4. Rank from 1 to 7 the indicated ways of communication with patients while getting feedback (where 1 is the most acceptable way):

\begin{tabular}{|l|l|l|}
\hline No & \multicolumn{1}{|c|}{ Communication way } & \multicolumn{1}{|c|}{ Ranking place } \\
\hline 4.1 & Direct communication during medical consultation & \\
\hline 4.2 .1$. & Distant communication by phone & \\
\hline 4.2 .2$. & Distant communication by e-mail & \\
\hline 4.2 .3$. & Distant communication by video call (Skype) & \\
\hline 4.2 .4$. & Distant communication by means of messengers (WhatsApp, Viber etc.) & \\
\hline 4.2 .5$. & Distant communication by means of social networks (Facebook, Instagram, VK etc.) & \\
\hline 4.2 .6$. & $\begin{array}{l}\text { Interactive online communication platform with personal area authentication (having function of data exchange including } \\
\text { voice and video calls) }\end{array}$ & \\
\hline
\end{tabular}

5. Rank from 1 to 7 the indicated ways of communication with colleagues while getting feedback in patients' support during postsurgical period (where 1 is the most acceptable way):

\begin{tabular}{|c|c|c|}
\hline № & Communication way & Ranking place \\
\hline 4.1 & Direct communication during personal contact & \\
\hline 4.2.1. & Distant communication by phone & \\
\hline 4.2.2. & Distant communication by e-mail & \\
\hline 4.2.3. & Distant communication by video call (Skype) & \\
\hline 4.2.4. & Distant communication by means of messengers (WhatsApp, Viber etc.) & \\
\hline 4.2.5. & Distant communication by means of social networks (Facebook, Instagram, VK etc.) & \\
\hline
\end{tabular}


4.6. Interactive online communication platform with personal area authentication (having function of data exchange including voice and video calls)

6. What kinds of barriers to support patients in postsurgical period exist for you personally?

5.1. Exceeding workload owing to tight surgeries schedule

5.2. Don't consider it possible to spend working time on incidental activities

5.3. See no necessity to spend my free time on this kind of activities

5.4. Other (please, write down)

7. What players, in your opinion, can be included in patents' support during postsurgical period?

6.1. Experienced orthopedic surgeons of the hospital providing surgery

6.2. Primary care physicians at the place of a patient's residence

6.3. Specially trained nurses at the place of a patient's residence

6.4. Social carers at the place of a patient's residence

6.5. Other (please, write down)

COMMON SECTION

8. Total medical experience:

8.1. Up to 5 years

8.2. $5-10$ years

8.3. $11-20$ years

8.4. More than 20 years

9. Work experience in orthopedic surgery:
9.1. Up to 5 лет
9.2. 5 -10 years
9.3. $11-20$ years
9.4. More than 20 years

10. Your company (please, write down)

11. Your position (please, write down)

12. Do you have an academic degree?
12.1. PhD
12.2. Doctor of science
12.3. Absent

13. Your remarks:

Thank you for your time! 